\title{
Fragmentation and drying ratchet down Great Plains stream fish diversity
}

\author{
JOSHUAH S. PERKIN ${ }^{\mathrm{a}, *}$, KEITH B. GIDO ${ }^{\mathrm{a}}$, KATIE H. COSTIGAN ${ }^{\mathrm{b}}$, MELINDA D. DANIELS ${ }^{\mathrm{c}}$ and ERIC R. JOHNSON \\ ${ }^{a}$ Division of Biology, Kansas State University, Manhattan, KS, USA \\ ${ }^{\mathrm{b}}$ Department of Geography, Kansas State University, Manhattan, KS, USA \\ ${ }^{\mathrm{c}}$ Stroud Water Resource Center Avondale, PA, USA \\ ${ }^{\mathrm{d}}$ Ecological Services Section, Kansas Department of Wildlife, Parks and Tourism, Wichita, USA
}

\begin{abstract}
1. Stream fragmentation alters the structure of aquatic communities on a global scale, generally through loss of native species. Among riverscapes in the Great Plains of North America, stream fragmentation and hydrologic alteration (flow regulation and dewatering) are implicated in the decline of native fish diversity.

2. This study documents the spatio-temporal distribution of fish reproductive guilds in the fragmented Arkansas and Ninnescah rivers of south-central Kansas using retrospective analyses involving 63 years of fish community data.

3. Pelagic-spawning fishes declined throughout the study area during 1950-2013, including Arkansas River shiner (Notropis girardi) last reported in 1983, plains minnow (Hybognathus placitus) in 2006, and peppered chub (Macrhybopsis tetranema) in 2012. Longitudinal patterns in fish community structure in both rivers consisted of strong breaks associated with dams, and pelagic-spawning fishes were missing from shorter fragments upstream of those barriers. Among downstream and longer fragments, probability of occurrence for pelagic-spawning fishes declined or fell to zero during periods of drought.

4. Based on these data, interactions between fragmentation and drying are hypothesized as operating as an ecological ratchet mechanism in which forward movement toward pelagic-spawning fish extirpation occurs during desiccation, and reciprocated reverse movement toward recolonization following return of flows is blocked by fragmentation.

5. The ratchet mechanism is capable of explaining the long-term 'ratcheting down' of fish diversity in Great Plains rivers and has implications for managing biodiversity in fragmented riverscapes where water is scarce or might become so in the future.

Copyright (C) 2014 John Wiley \& Sons, Ltd.
\end{abstract}

Received 8 April 2014; Revised 3 July 2014; Accepted 21 July 2014

KEY WORDS: river; stream; biodiversity; reproduction; fish; drought; impoundment

\section{INTRODUCTION}

Habitat fragmentation and loss threaten biodiversity and ecosystem integrity on a global scale (Dudgeon et al., 2006; Pardini et al., 2010). In streams and rivers, fragmentation and loss are particularly problematic because of the naturally occurring

*Correspondence to: Joshuah S Perkin, Department of Biology, Tennessee Technological University, 1100 N. Dixie Avenue, Cookeville, TN 38505. E-mail: jperkin@tntech.edu 
hierarchical organization and dendritic (branching) arrangement of habitats, which limit dispersal paths for organisms confined to water (Campbell Grant et al., 2007). In stream and river networks (herein 'riverscapes' sensu Fausch et al., 2002), fishes represent a group of organisms confined to within-network movement with increasingly well-documented responses to riverscape fragmentation (Fullerton et al., 2010; Perkin and Gido, 2012). In fragmented riverscapes, there are notable declines in fish biodiversity (Liermann et al., 2012), size and connectivity of populations (Junge et al., 2014), dispersal opportunities (Perkin et al., 2013a; Rolls et al., 2013), and resistance and resilience to stochastic extinctions (Dunham et al., 2004). Consequently, the global pattern of stream fragmentation has led to considerable change to riverine fish faunas (Lehner et al., 2011; Cooke et al., 2012). In particular, habitat fragmentation coupled with naturally occurring or anthropogenically magnified disturbance regimes have contributed to directional and irreversible change to stream fish distributions (Roberts et al., 2013). Changes to stream fish abundances and distributions brought on by interactions between fragmentation and disturbance regimes probably operate through processes similar to those governing organisms in other fragmented ecosystems (e.g. terrestrial or marine systems; Roques and Stoica, 2007), although conceptual frameworks are currently lacking for application to riverscapes (Pringle, 2003; Rolls et al., 2013).

Self-reinforcing processes that degrade populations and disrupt community or ecosystem structuring reflect 'ecological ratchets'. The ecological ratchet concept was originally used to describe dynamics of marine fish stocks (Caddy and Gulland, 1983; Ludwig et al., 1993), but has been applied to coral reef ecology (Birkeland, 2004), marine food webs (Thrush and Dayton, 2010), and terrestrial plant communities (Jackson et al., 2009). The ratchet concept involves forward movement (change) in a given response variable (e.g. species distributions) through space or time in response to natural or human disturbance(s) without reciprocal reverse movement (resetting of change), which is typically blocked through some introduced or derived mechanism(s) and ultimately results in continued or irreversible degradation (Birkeland, 2004). Thus, ecological ratchets require three key components: some response variable, a form of disturbance (natural or anthropogenic) that elicits change in the response variable, and an introduced or derived mechanism that prohibits resetting of the observed change in the response variable. Ratchets might operate as mechanisms for species expansion and thus new invasions (Jackson et al., 2009) or decline and thus extirpations (Birkeland, 2004); however, an advantage to this conceptual framework is that it might be applied to a variety of organisms occupying diverse ecosystems, including fishes occupying fragmented riverscapes. Fish distributions in riverscapes are changing on a global scale in response to ecosystem variability (a natural change) or degradation (an anthropogenic change) and provide a useful response variable for observing change within stream ecosystems (Simon, 1999). Hydrologic variability is among the strongest drivers of ecological change within riverscapes, and disturbances related to floods and droughts exist within most stream ecosystems on Earth (Poff and Ward, 1989; Matthews and Marsh-Matthews, 2003). In addition, longitudinal connectivity within riverscapes has been fragmented and is implicated in the largely irreversible processes of fish biodiversity loss (Lehner et al., 2011; Liermann et al., 2012). Although the necessary components for ratchet manifestation are documented within riverscapes, the extent to which the global processes of habitat fragmentation and hydrologic disturbance are operating to ratchet-down (species loss) or ratchet-up (species invasions) fish species distribution remains largely unaddressed despite the considerable implications for ecosystem conservation and restoration (Januchowski-Hartley et al., 2013).

Great Plains stream fishes evolved under connected riverscapes characterized by broadly fluctuating environmental conditions including frequent disturbances caused by flooding and drought (Dodds et al., 2004). However, contemporary riverscapes in this region are highly fragmented (>19000 barriers, Figure S1), characterized by regulated stream flows with dampened flooding (Costigan and Daniels, 2012), and routinely become dewatered because of surface and groundwater depletion (Falke et al., 2011). Associated with these riverscape alterations, broad-scale changes in community composition 
have occurred (Gido et al., 2010) and 65\% of endemic species have declined because of fragmentation (Hoagstrom et al., 2011). The greatest magnitude of community change is evident among historically abundant and wide-spread smallbodied fishes in the family Cyprinidae ('cyprinids' hereafter), especially for species that belong to the pelagic-spawning reproductive guild (Hoagstrom and Turner, 2013; Perkin et al., 2014). Fishes that broadcast non-adhesive, drifting eggs into the pelagic zones of Great Plains rivers declined massively during the past half century (Dudley and Platania, 2007; Gido et al., 2010), including threshold responses to fragmented riverscapes (Perkin and Gido, 2011; Wilde and Urbanczyk, 2013). In some cases, pelagic-spawning fish extirpations occur when the effects of fragmentation occur in concert with desiccation disturbances, either in the form of water withdrawal by humans (Perkin et al., 2014) or periodic droughts (Kelsch, 1994; Perkin et al., 2013b). These community shifts have persisted through time $(40+$ years in some rivers; Gido et al., 2002), suggesting a level of reinforcement by current environmental conditions (Luttrell et al., 1999). However, the relationship between disrupted mechanisms of community structuring and extensive fragmentation of Great Plains riverscapes lacks conceptual synthesis capable of explaining the directional and reinforced change in fish communities throughout the region.

This study applies an ecological ratcheting framework to changes in fish community structure brought on by habitat fragmentation and hydrologic disturbance in the Great Plains, USA. The goal of this novel approach is to shed light on the mechanism(s) responsible for broad-scale and long-term declines among native and endemic Great Plains fishes as documented in other recent works (Perkin et al., 2014; Worthington et al., 2014). Specific objectives include: (i) testing for long-term (1950-2013) change in the probability of occurrence for cyprinid fishes belonging to common reproductive guilds in the central Great Plains, USA; (ii) assessing change in fish community structure upstream and downstream of barriers that potentially fragment longitudinal connectivity; and (iii) evaluating fish response to hydrologic desiccation during drought disturbances. The objectives of the current study are related to each of the three key components of ecological ratcheting, including change in fish distributions (i.e. response variable), fish sensitivity to droughts (i.e. disturbance), and reinforcement of observed change by fragmentation of riverscapes (i.e. human-induced mechanism that blocks resetting).

\section{MATERIALS AND METHODS}

\section{Study area}

The Arkansas River and its tributary the Ninnescah River in south-central Kansas are representative Great Plains streams that have experienced groundwater depletion (i.e. extraction $>$ recharge) and surface water diversion and retention. Both are sand-bed rivers characterized by braided, shallow, and wide channels with sediment transport at most stages (Costigan et al., 2014). The Arkansas River is dry nearly year-round upstream of Great Bend, KS because of depletion of the High Plains Aquifer (Steward et al., 2013), and many fish species that historically inhabited the river are now extirpated between this point and the Colorado-Kansas border (Gido et al., 2010). Surface water alterations include Cheney Reservoir (constructed in 1969) on the North Fork Ninnescah River and Kaw Reservoir (constructed in 1975) on the Arkansas River just downstream of the Kansas-Oklahoma border (Figure 1). Longitudinal fragmentation occurs in the form of multiple small dams, located in the cities of Wichita, KS on the Arkansas River (two dams, built c. 1975) and Kingman, KS on the Ninnescah River (one dam, Figure S2). These structures are run-of-the-river dams that do not retain water for long-term storage. The downstream dam near Wichita, KS underwent reconstruction during the period of study and is now fitted with a fish passage channel (Figure S3), although this channel remained dry or closed during the extent of the study because of drought and structural failures.

\section{Fish community data and reproductive guilds}

Historical and contemporary fish collection data were obtained for the Arkansas River between Great Bend, KS and Kaw Reservoir and the Ninnescah River between Pratt, $\mathrm{KS}$ and the confluence with the Arkansas River for the period 


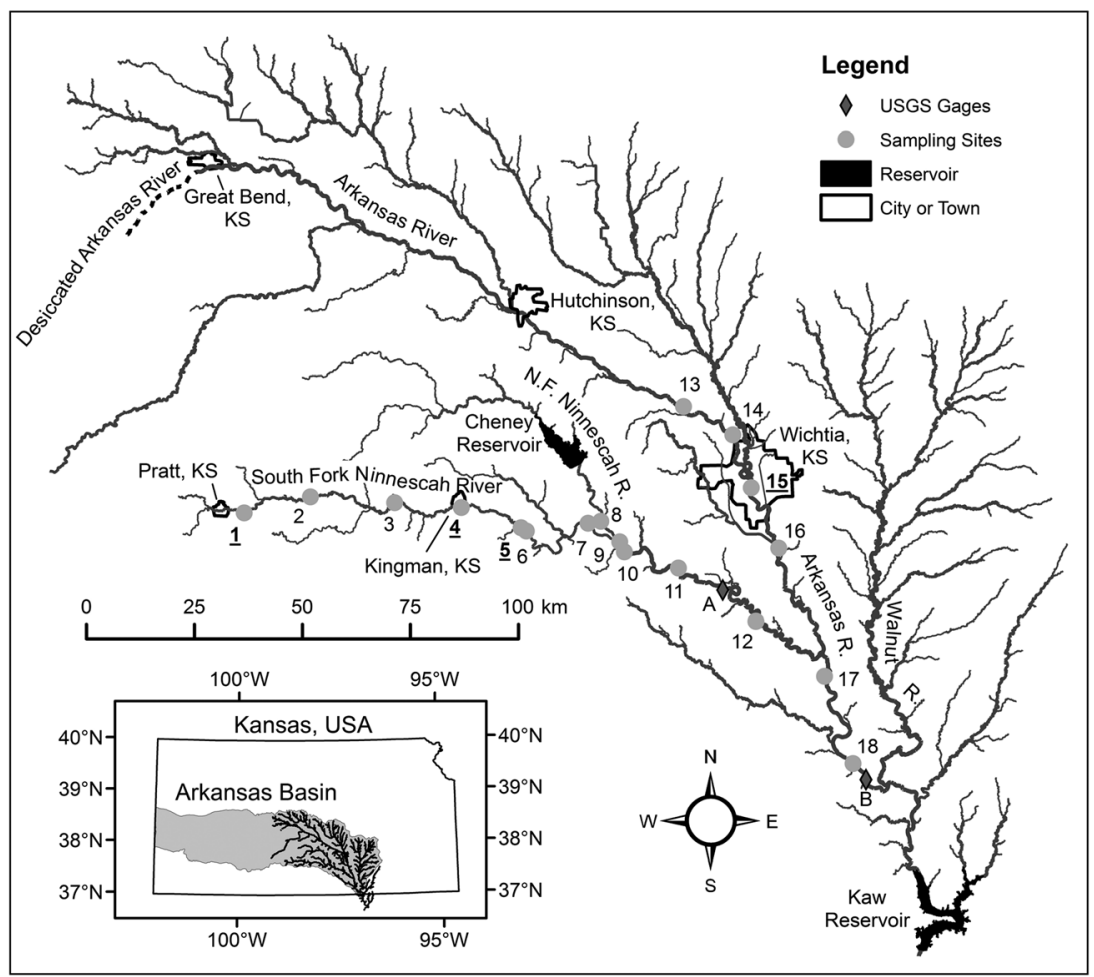

Figure 1. Locations of the Arkansas and Ninnescah rivers of south-central Kansas. Sites for 2011-2013 sampling are shown; those immediately downstream of low-head dams are labelled with bold and underlined numbers (see Figure S2 for pictures of dams). Locations of US Geological Survey streamflow gauges are shown as lettered diamonds.

1950-2013. Fish community collections for these rivers were extracted from the Kansas Aquatic Gap Program as described by Gido et al. (2010) and supplemented by two additional datasets. The first dataset was collected by the City of Wichita during 2000-2008 as a part of standardized monitoring of the Arkansas River, including two sites upstream and five sites downstream of the series of dams in the city (Vaughn Weaver, unpublished data). These data were collected using a combination of seining and electrofishing during summer months in which entire communities and all available habitats were targeted. The second dataset consisted of collections made by the authors during 2011-2013 among 18 sites distributed along the Arkansas $(n=6)$ and Ninnescah $(n=12)$ rivers. Sampling sites were visited fortnightly during 2011 and 2012 summers (May-August) and fish communities were sampled from all available habitats using a seine $(4.6 \times 1.8 \mathrm{~m}, 3.2 \mathrm{~mm}$ mesh) for a period of at least $1 \mathrm{~h}$. The area $\left(\mathrm{m}^{2}\right)$ of each seine haul was recorded to allow calculation of fish density (number of fish/area sampled). Monitoring was continued for a subset of these sites (three at the downstream extent of each river) using the same methods during the summer of 2013.

Cyprinid fishes reported in these databases were classified into four reproductive guilds based on spawning behaviour, habitat, and egg characteristics (Table 1). Guilds were based on Balon (1975) and described and reviewed in detail by Simon (1999). Pelagic spawners (pelagophilic) release non-adhesive, drifting eggs within the pelagic zone (open water) of the stream without regard to substrate; pelagic substrate-spawners (lithopelagophilic) have non-adhesive, demersal (sinking) eggs released within the pelagic zone and over sand or gravel substrate; substrate spawners (lithophilic) have adhesive, demersal eggs released over sand or gravel substrate; crevice spawners (speleophilic) have adhesive, demersal eggs deposited over nests or within cracks or crevices of the benthos. Existing literature sources were used for all guild classifications (Table 1). 
Table 1. Species reproductive guilds, abundance rank (total individuals collected) for 2011-2012 sampling by authors, reproductive season, and conservation status of fishes included in this study

\begin{tabular}{|c|c|c|c|c|}
\hline \multicolumn{2}{|c|}{ Reproductive guild ${ }^{1}$} & Rank (number collected) & Reproductive season ${ }^{2}$ & Conservation status ${ }^{3}$ \\
\hline \multicolumn{5}{|c|}{ Pelagic (Pelagophilic) } \\
\hline PM & Plains minnow Hybognathus placitus & $0(0)$ & April - August & Vulnerable \\
\hline ARS & Arkansas River shiner Notropis girardi & $0(0)$ & June - August & Endangered \\
\hline \multicolumn{5}{|c|}{ Pelagic-Substrate (Lithopelagophilic) } \\
\hline $\mathrm{SC}$ & Silver chub Macrhybopsis storeriana & $7(447)$ & April - July & No listing \\
\hline CSR & Central stoneroller Campostoma anomalum & $6(893)$ & March - May & No listing \\
\hline SS & Sand shiner Notropis stramineus & $3(36,783)$ & April - August & No listing \\
\hline SMM & Suckermouth minnow Phenacobius mirabilis & $5(1,506)$ & April - August & No listing \\
\hline \multicolumn{5}{|c|}{ Crevice (Speleophilic) } \\
\hline RS & Red shiner Cyprinella lutrensis & $1(83,721)$ & May - September & No listing \\
\hline FHM & Fathead minnow Pimephales promelas & $9(87)$ & April - August & No listing \\
\hline
\end{tabular}

${ }^{1}$ Simon (1999),

${ }^{2}$ Cross and Collins (1995),

${ }^{3}$ Jelks et al. (2008).

\section{Data analyses}

The first objective was to test for long-term changes in the probability of occurrence for fishes during 1950-2013. Data from the multiple sources were combined and abundances transformed to presence-absence (Gido et al., 2010). Occurrence data for the 12 most common cyprinid fishes over the course of the 63-year period were extracted and grouped according to their reproductive mechanism. Long-term trends in the probability of occurrence $(0=$ absent, $1=$ present $)$ for each species were tested using a generalized estimation equation to account for autocorrelation among samples taken close together in time. Binomial logistic equations were fitted assuming an auto-regressive correlation structure in the data (Zuur et al., 2009) using the geepack Package in Program R (Halekoh et al., 2006). The modelled mean and $95 \%$ confidence intervals, slope of the regression, Wald test statistic, and $P$-value for probability of occurrence of each species were then plotted through time to illustrate temporal changes in fish distributions.

The second objective was to assess the effects of small barriers on fish community structure in each river. Longitudinal changes in fish community structure were assessed in each river using data collected during the summers of 2011 and 2012 from river fragments upstream and downstream of the small dams in each river. This analysis process began with construction of a Bray-Curtis distance matrix (Bray and Curtis, 1957) based on fish densities from the 18 sampling sites across the 2 years of intense sampling. Occurrence of longitudinal breaks in community structure caused by fragmentation was tested in the Arkansas and Ninnescah rivers separately. Sites were systematically grouped beginning with the most upstream site versus all remaining sites, then the first two upstream sites versus all remaining sites, and so on until a theoretical community break was inserted between all possible longitudinal groups of sites in each river. Significant clustering among groups was tested using a permutational multivariate analysis of variance (pMANOVA) on the Bray-Curtis distance matrix, which allowed for calculating a coefficient of determination $\left(r^{2}\right)$ value for each theoretical community break. Location of the strongest community break in each river was assessed using pMANOVA $r^{2}$ results and compared with barrier locations to evaluate agreement between breaks in community structure and stream fragmentation. Differences between the groups upstream and downstream of the strongest break in community structure were illustrated using non-metric multi-dimensional scaling (NMDS) bi-plots. All statistics were conducted in Program $\mathrm{R}$ using the vegdist (Bray-Curtis), adonis (pMANOVA) and 
nmds (NMDS) functions in the Vegan Package (Oksanen et al., 2007).

The third objective was to evaluate fish reproductive guild responses to drought. This objective was developed in part because of the fortuitous timing of a major drought during 2011 and 2012 sampling years (Figure S4). Since preliminary results suggested that fish community structure did vary longitudinally, further testing was used to assess changes in fish distributions upstream and downstream of barriers as well as during periods of drought. Occurrences (presence or absence) were analysed using a random sub-sampling approach as outlined in Gido et al. (2010) to avoid potential bias caused by non-independence of samples either in space or time. In particular, $80 \%$ of the minimum number of samples taken upstream or downstream of barriers across years was randomly sub-sampled without replacement 1000 times and the mean $( \pm 95 \%$ confidence interval) probability of occurrence calculated. For temporal patterns, a similar approach involving sub-sampling $80 \%$ of the minimum number of collections across years was used only for the downstream communities since preliminary results suggested that some reproductive guilds did not occur in the upstream portions of each river. Differences across space and time were considered significant if $95 \%$ confidence intervals did not overlap (Gido et al., 2010). Spatio-temporal patterns in probability of occurrence were plotted for the 2000-2008 and 2011-2013 periods separately to control for differences in collection gears and efforts.

Drought and streamflow data were compared with fish occurrence probabilities to illustrate responses to desiccation disturbance. Palmer Drought Severity Index values from the National Climate Data Center operated by the National Oceanic and Atmospheric Administration (http://www.ncdc. noaa.gov/temp-and-precip/drought/historical-palmers. php, last accessed 1 February 2014) were used to quantify annual variation in drought. Historical records (1950-2013) were downloaded for the climatological division covering the extent of the study area in south-central Kansas (Division \# 14-08). Historical streamflow data (1950-2013) were extracted from two USGS gauges located at the downstream extent of the Arkansas River (gauge \# 07146500) and the Ninnescah River (gauge \# 07145500). Streamflow data were analyzed using Indicators of Hydrologic Alteration (IHA; Richter et al., 1996) to determine mean annual stream flow during cyprinid reproductive seasons (March-September) as well as long-term mean $( \pm 95 \%$ confidence interval) streamflow for the Arkansas and Ninnescah rivers. Palmer Drought Severity Index values $<-2$ were considered moderate drought and values $<-3$ were considered severe drought. Mean annual streamflow magnitudes below the lower 95\% confidence level (i.e. non-overlapping confidence intervals) of average flows were considered exceptionally dry years. Continuous occurrence data for fish collections taken during the two most recent datasets (City of Wichita and the authors) were then compared with desiccation disturbance periods to assess responses to drought.

\section{Conceptualizing the ratchet}

A conceptual model detailing the three components of an ecological ratchet at the sub-basin scale (i.e both Arkansas and Ninnescah rivers) was used to synthesize findings. Fish distribution data were used to assign an approximate last year of collection for pelagic-spawning fishes throughout the sub-basin. Drought disturbance for the region and flow data for the downstream extent of both rivers were combined to identify exceptionally low streamflow throughout the sub-basin. A measure of long-term habitat connectivity for the sub-basin was obtained from Perkin et al. (2014); this measure of connectivity was the potadromous component of the Dendritic Connectivity Index (DCI) developed by Cote et al. (2009). A DCI value of 100 indicates complete natural connectivity among all habitats in a network, and this value declines toward zero with increased fragmentation caused by artificial barriers (Cote et al., 2009; Perkin et al., 2014). The ratchet mechanism was conceptualized by simultaneously illustrating estimated last occurrences of fishes, drought disturbances, and longitudinal habitat connectivity through time (1950-2013) for the entire sub-basin. Insights gained from this approach were further illustrated as a conceptual diagram that demonstrated how changes in fish distributions might be ratcheted by the interaction between fragmentation and drought disturbance. 


\section{RESULTS}

Review of historical fish data resulted in 274 collections included in the long-term analysis of occurrence probabilities. Sixty-four collections were obtained from the Kansas Aquatic Gap Database, 67 from the City of Wichita, and 143 by the authors during 2011-2013. Probability of occurrence changed through time for eight of the 12 species (Figure 2). Logistic regression indicated a significant decline through time for pelagic-spawning Arkansas River shiner (Notropis girardi) and plains minnow (Hybognathus placitus) but no change for peppered chub (Macrhybopsis tetranema). All of these pelagic-spawning fishes were missing from collections during 2013 and a review of historical data indicated that the last reports were in 1983 for Arkansas River shiner, in 2006 for plains minnow, and in 2012 for peppered chub. Pelagic substrate-spawning fishes increased through time, including silver chub (Macrhybopsis storeriana) and emerald shiner (Notropis atherinoides). Substrate-spawning fishes generally increased, including sand shiner (Notropis stramineus) and suckermouth minnow (Phenacobius mirabilis), but no change for central stoneroller (Campostoma anomalum). Crevice-spawning red shiner (Cyprinella lutrensis) and bullhead minnow (Pimephales vigilax) increased, but there was no change for fathead minnow (Pimephales promelas) or bluntnose minnow (Pimephales notatus).

Longitudinal variability in cyprinid community structure based on 2 years of intensive sampling

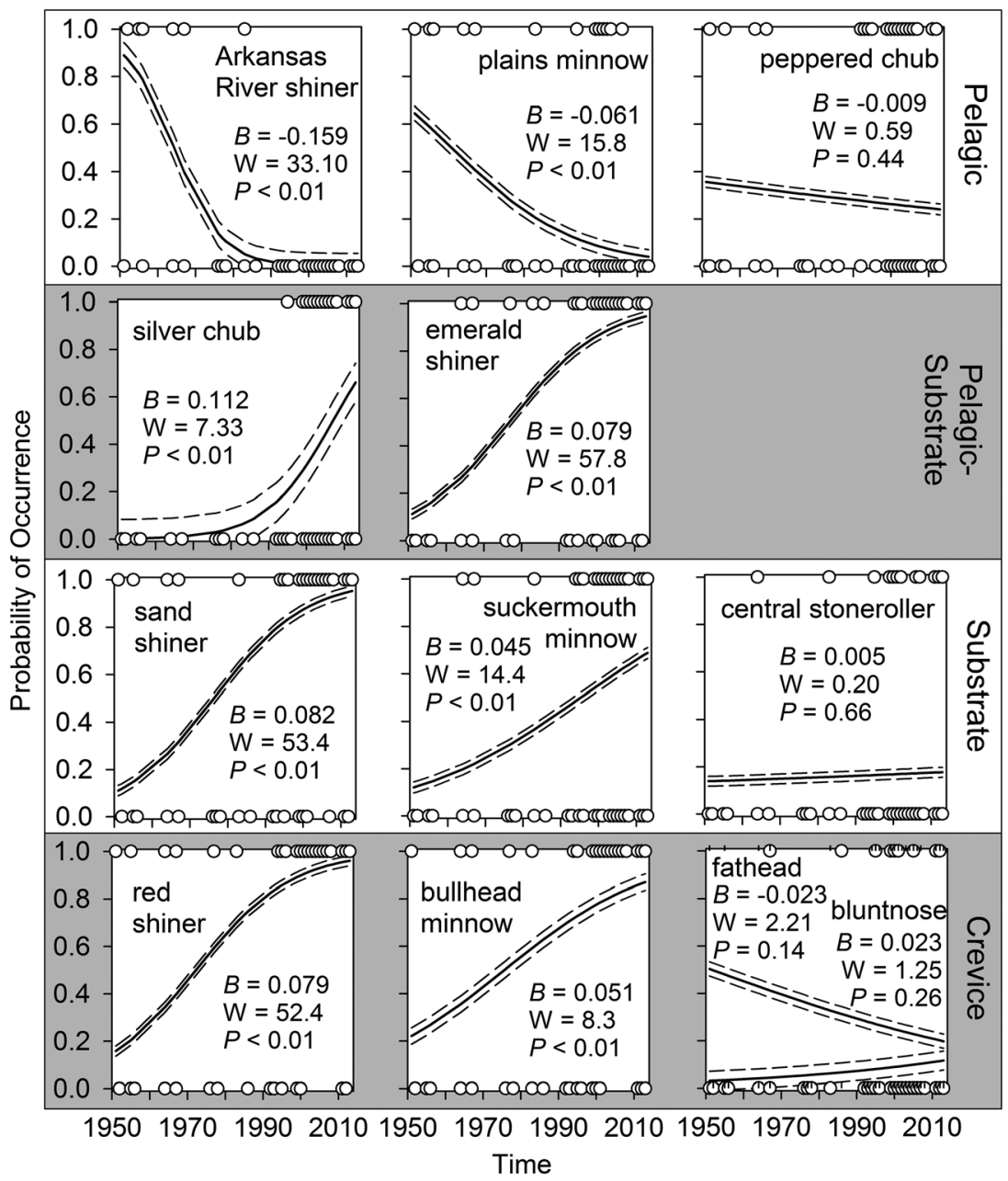

Figure 2. Long-term (1950-2013) trends in the probability of occurrence for cyprinid fishes in the Arkansas and Ninnescah rivers of south-central Kansas. Logistic generalized equation estimations (solid lines), 95\% confidence intervals (dashed lines), and statistics ( $B=$ slope, $\mathrm{W}=\mathrm{Wald}$ value, $P$-value) are shown for collections (white points) in which each species was present (occurrence $=1$ ) or absent (occurrence $=0)$. 
revealed strong breaks in the Arkansas and Ninnescah rivers. Theoretical community breaks iteratively inserted between sites in the Arkansas River produced significant models in all cases (pMANOVA $P<0.05 ; r^{2}=0.08-0.19$ ), and the strongest model (Pseudo $F_{1,80}=18.3 ; r^{2}=0.19$, $P<0.001)$ corresponded with the barriers between sites 14 and 15 (Figure 3(A)). Theoretical community breaks in the Ninnescah River produced significant models in all cases (pMANOVA $P<0.05 ; r^{2}=0.02-0.22$ ), and the strongest break (Pseudo $F_{1,206}=59.0 ; r^{2}=0.22$, $P<0.001)$ corresponded with the permanent barrier location upstream of Site 4 (Figure 3(B)). Two-dimensional NMDS plots were characterized by low stress values $(<0.15)$ and strong clustering of community samples taken upstream and downstream of barriers in the Arkansas (Figure 3(C)) and Ninnescah (Figure 3(D)) rivers. Separation of sites in NMDS plots was driven in part by absence of fish species among upstream sites in both rivers
(Table 2), including pelagic-spawning peppered chub as well as pelagic substrate-spawning emerald shiner and silver chub.

During 2000-2013, temporal patterns in probability of occurrence for fishes downstream of barriers in the Arkansas and Ninnescah rivers were consistent among river systems and reproductive guilds. Arkansas River shiner was not collected during 2000-2008, nor was the species observed during 2011-2013. Similarly, although plains minnow was captured during 2000-2008, the species was not observed during 2011-2013. Downstream of the dams on the Arkansas River, the probability of occurrence for pelagic-spawning plains minnow and peppered chub declined during 2001-2003 and then again during 2006-2008 (Figure 4). During the second decline, probability of occurrence for both pelagic-spawning fishes declined to zero. Fishes belonging to the remaining reproductive guilds persisted through time. In the Arkansas and Ninnescah rivers during 2011-2013, the probability
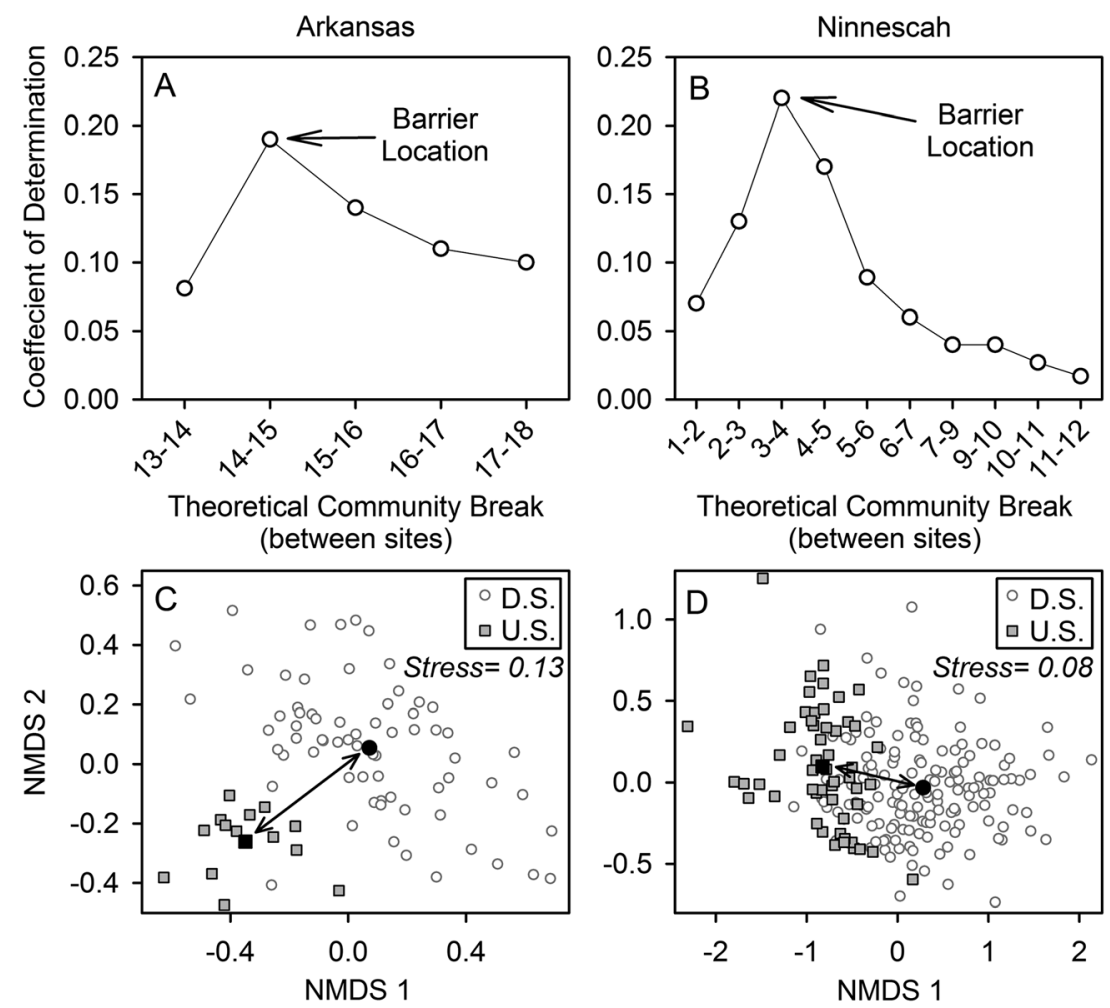

Figure 3. Spatial variability in cyprinid community structure for streams in south-central Kansas. The most variation (maximum coefficient of determination) corresponded with barriers in the (A) Arkansas and (B) Ninnescah rivers and was associated with strong clustering of collections upstream (U.S., white symbols) and downstream (D.S., grey symbols) of barriers as illustrated by non-metric multi-dimensional scaling (NMDS) bi-plots for the (C) Arkansas and (B) Ninnescah rivers (black symbols connected by arrows are means). 
RATCHETING DOWN FISH DIVERSITY

Table 2. Mean probability of occurrence (95\% confidence interval) for cyprinid fishes upstream and downstream of barriers in the Arkansas and Ninnescah rivers of south-central, Kansas. Fishes that were historically present but not collected during sampling are indicated (-)

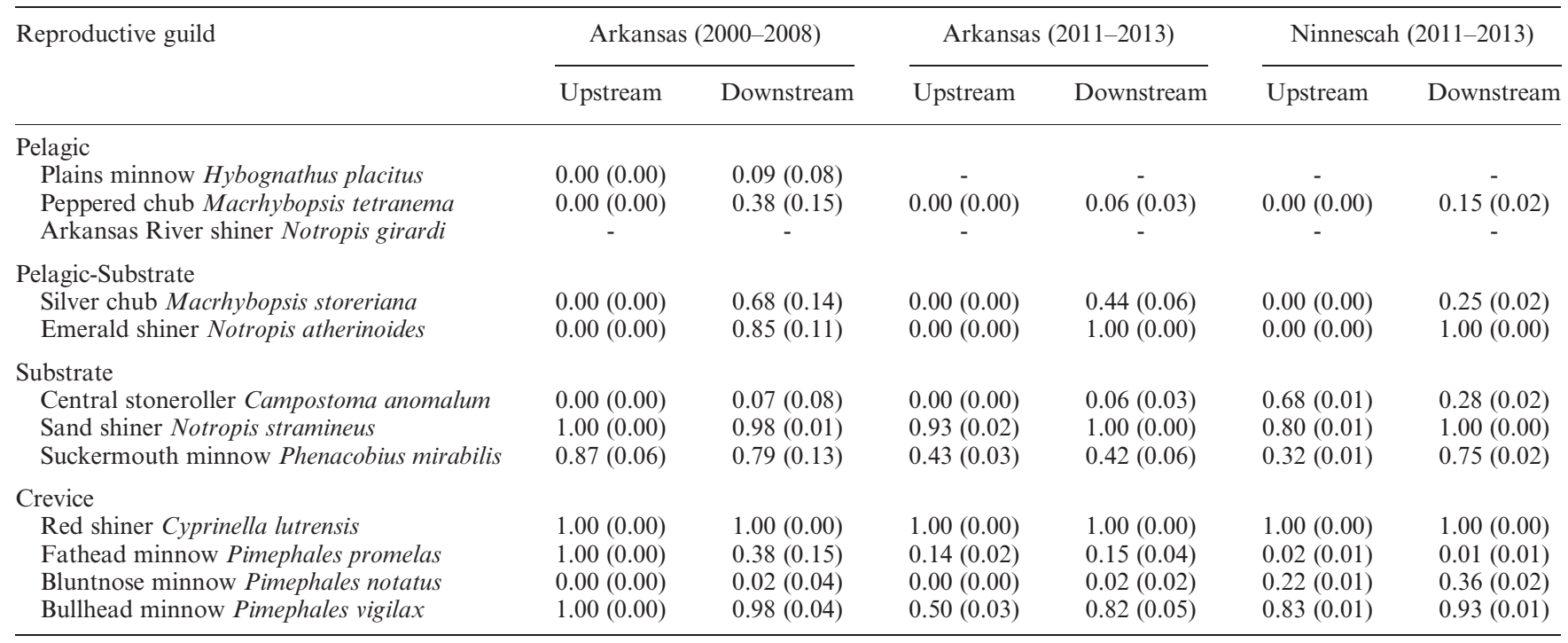

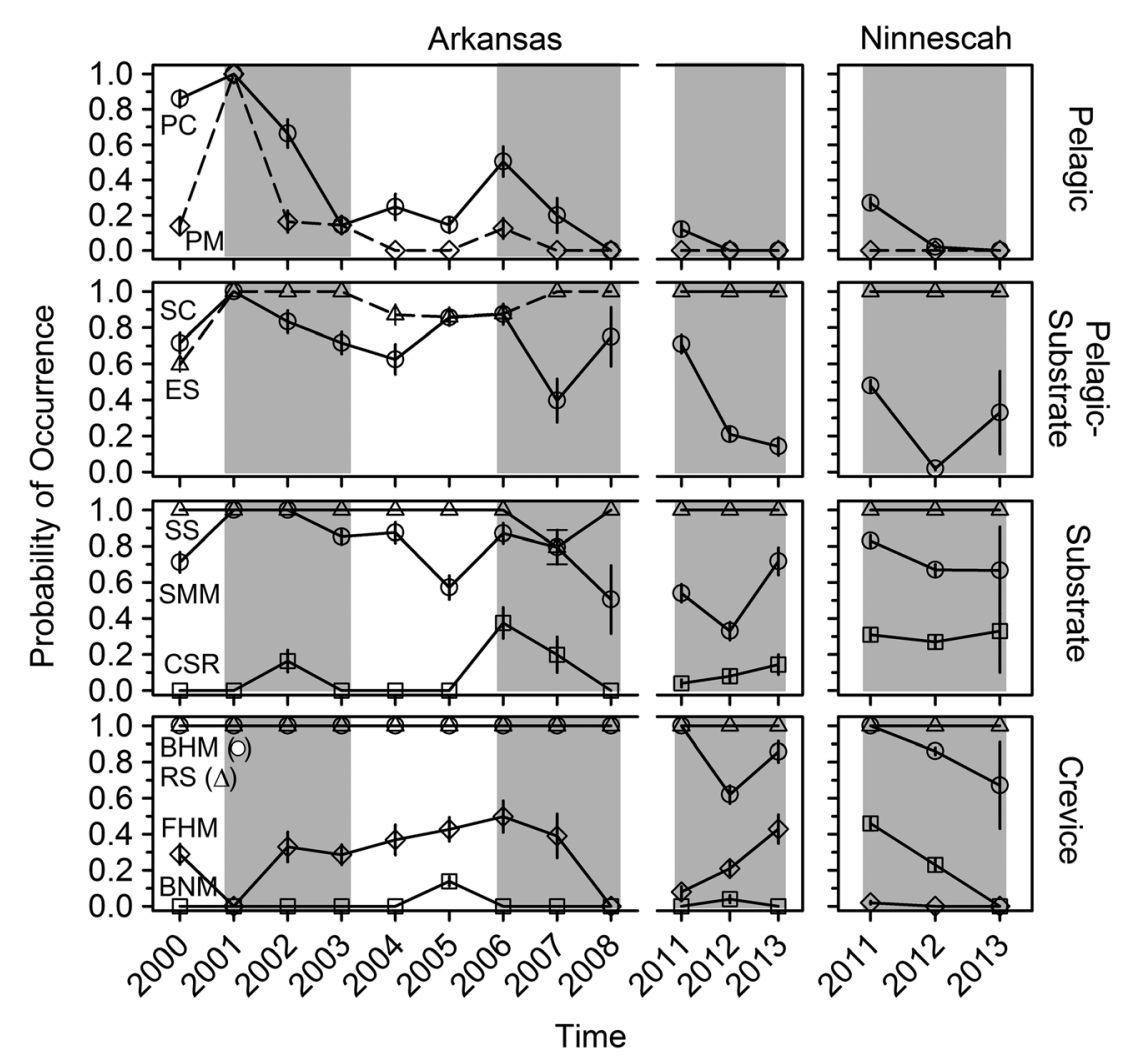

Figure 4. Temporal variability in mean $( \pm 95 \%$ confidence interval) probability of occurrence for fishes belonging to four reproductive guilds downstream of dams on the Arkansas and Ninnescah rivers in south-central Kansas. Species are labelled using two- or three-letter codes (see Table 1) and drought cycles are shaded grey. 
of occurrence for peppered chub, the only remaining pelagic-spawning fish, declined over the course of 3 years in both rivers so that no individuals were collected during summer 2013 in either river system following severe drought. The remaining reproductive guilds generally persisted through time with only silver chub indicating consistent declines in both rivers.

The timing of declines and last reports for pelagic-spawning fishes occurred after fragmentation of the Arkansas River basin and correlated with drought periods when stream flows were below average. Construction of Keystone Reservoir (downstream of Kaw Reservoir in Oklahoma) in 1964 reduced the amount of longitudinal connectivity by half, followed by additional fragmentation by Cheney Reservoir in 1969 and construction of Kaw Reservoir and the dams near Wichita in 1975 (Figure 5). There was no additional fragmentation in the basin after 1975. Although severe drought occurred throughout the study area during 1953-1956 (Figure 5(A)), the first moderate drought following basin-wide fragmentation occurred during 1981. Normal or wetter-than-normal years occurred after
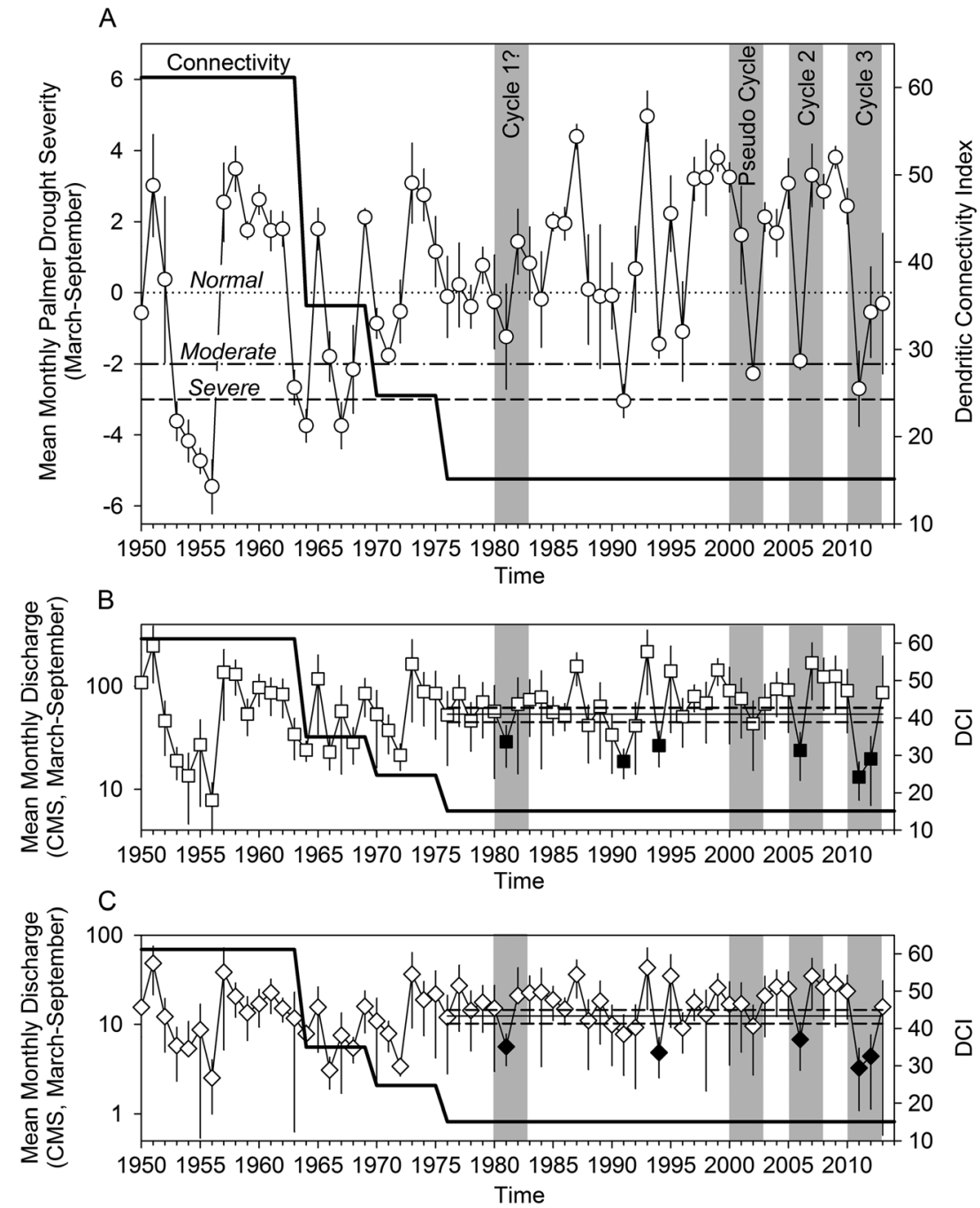

Figure 5. (A) Drought records for south-central Kansas illustrating mean ( $\pm 95 \%$ confidence interval) Palmer Drought Severity Index (white circles) across cyprinid reproductive months (March-September). The solid black line illustrates change in habitat connectivity through time (see text), grey shades represent cycles of an ecological ratchet mechanism. (B) Mean streamflow ( $\pm 95 \%$ CI) for the Arkansas River (US Geological Survey gauge 07146500; squares) and long-term mean $( \pm 95 \%$ CI) across years (solid and dashed black lines) illustrated for the period following fragmentation; exceptionally dry years are shown in black. (C) Streamflow data for the Ninnescah River (gauge 07145500); symbols are as in panel B. 
this period with a punctuated moderate drought in 1989, a severe drought in 1991, moderate droughts during 1996, 2002, and 2006, and a severe drought during 2011. Within these drought periods, streamflow in the Arkansas River was exceptionally low during 1981, 1991, 1994, 2006, and 2011-2012 (Figure 5(B)). Similarly, streamflow in the Ninnescah River was exceptionally low during 1981, 1994, 2006, and 2011-2012 (Figure 5(C)). The last reported records of Arkansas River shiner (1983), plains minnow (2006), and peppered chub (2012) each occurred during or shortly after (within 2years) droughts that caused low flow conditions in both rivers (i.e, throughout the sub-basin).

\section{DISCUSSION}

Stream fish communities in the Great Plains of North America changed considerably during the past half century owing to the effects of fragmentation and dewatering (Gido et al., 2010; Hoagstrom et al., 2011). Although the individual effects of dewatering (Cross et al., 1985; Durham and Wilde, 2009) and fragmentation (Perkin and Gido, 2011; Wilde and Urbanczyk, 2013) have been evaluated, recent broad-scale analyses suggest that these processes act in concert to cause declines among some fishes, especially pelagic-spawning species (Perkin et al., 2014). The current study builds upon existing knowledge in at least three ways. First, results suggest that long-term declines among multiple pelagic-spawning fish species are driven by similar processes and have occurred during a period of increases for most other fishes, highlighting the utility of approaches that target ecotypes or guilds in restoration (Dudley and Platania, 2007; Worthington et al., 2014). Second, data collected in this study indicate that even small dams $(<5 \mathrm{~m}$ height $)$ are capable of causing longitudinal fragmentation of Great Plains fish communities in a manner consistent with much larger structures (Winston et al., 1991; Luttrell et al., 1999). Perhaps most significantly, this study provides a mechanistic underpinning for the correlative relationship between stream fragmentation and the disappearance of pelagic-spawning fishes throughout the Great Plains (Perkin et al., 2014).

\section{Disappearance of pelagic-spawning fishes}

Long-term patterns in the probability of occurrence for fishes in the Arkansas and Ninnescah rivers were characterized by declines among pelagic-spawning fishes and increases or no change among fishes in remaining reproductive guilds. The first species to disappear was the now federally 'Threatened' Arkansas River shiner (missing from $80 \%$ of historic range; Wilde, 2002) during the 1980s. Despite more than 230 Arkansas River shiner and 220 peppered chub being collected in the Ninnescah River during the late 1970s (KFGC, 1978), visits to the same area as well as the Arkansas River proper following the drought of 1981 by Cross et al. (1985) produced no Arkansas River shiner and no peppered chub. Although peppered chub was encountered among collections following the work of Cross et al. (1985), Arkansas River shiner was never collected again after a single report by Cross in 1983 (Kansas Aquatic Gap Program; Cross's Notes: C-11-83). Based on the effects of fragmentation and dewatering on the timing of disappearance and vulnerability of Arkansas River shiner (Worthington et al., 2014), we hypothesize that disappearance of the species was related to the effects of the first moderate drought in the extensively fragmented riverscape. Similarly, plains minnow was last reported in the vicinity of Wichita, KS during the midst of a moderate drought in 2006, but 152 collections taken from the area since did not produce a single specimen. Although the data on peppered chub did not indicate long-term declines during 1950-2013, contemporary and intensive surveys documented the decline and eventual disappearance of the species in the Arkansas and Ninnescah rivers during the drought cycle of 2010-2013. Peppered chub is missing from 90\% of its historical range because of the effects of fragmentation (Luttrell et al., 1999) and stream desiccation (Wilde and Durham, 2008), and data presented in this study indicate substantial decline of this last remaining pelagic-spawning species in the riverscape. Continued sampling in the area is urgently necessary to determine if peppered chub numbers have declined to zero or simply below the point of detection. The latter was probably the case during work by Cross et al. (1985) and the species 
did eventually recover to detectable abundances. Regardless, long-term fish occurrences suggest that pelagic-spawning fishes responded similarly to the two major forms of landscape alteration in the Great Plains - fragmentation and desiccation (Hoagstrom et al., 2011) - and that conservation approaches that benefit one member of this reproductive guild are likely to benefit the others. Acknowledging that sampling gears and efforts changed during 1950-2013, we believe the long-term changes reported here are accurate given similarities to other reported trends for the region (Gido et al., 2010) and the fact that species disappeared in spite of the potential for increased gear efficiency through time (Patton et al., 1998).

\section{Fragmentation by small dams}

Spatial variability in species occurrences suggest that pelagic-spawning and pelagic substrate-spawning fishes were sensitive to the effects of fragmentation caused by small dams. Dam locations corresponded to strong breaks in community structure in both the Arkansas and Ninnescah river systems. These breaks in community structure were driven in part by the absence of pelagic-spawning and pelagic substrate-spawning fishes upstream of the barriers. During 2000-2008 in the Arkansas River, no members of either guild were recorded upstream of the series of dams in Wichita, KS. This pattern continued for collections made during 2011-2012 for the Arkansas River as well as the Ninnescah River and all remaining pelagic and pelagic substrate-spawning fishes in the riverscape were missing upstream of small dams in Wichita and Kingman, KS. Although documented occurrences indicate that fishes belonging to these guilds once occupied the now fragmented upstream portions of both rivers (Cross, 1967), small dams have apparently truncated longitudinal distributions. All pelagic-spawning and pelagic substrate-spawning fishes included in this study have experienced range reductions caused by fragmentation throughout the Great Plains (Perkin and Gido, 2011; Perkin et al., 2014), but the results presented here extend the known effects of fragmentation beyond mostly large structures to include even small diversion dams (Winston et al., 1991; Luttrell et al., 1999).

\section{Ratcheting-down Great Plains fish diversity}

Both the Arkansas and Ninnescah rivers have surface water retention structures (large reservoirs) and extraction structures (small dams) that fragment longitudinal connectivity, and reduce streamflow (Costigan and Daniels, 2012). In addition to continuing groundwater extraction in the area (Steward et al., 2013), these activities create flow regimes that select for fish species resistant to the effects of stochastic stream desiccation (i.e. drought) by the very nature of removal of water that would otherwise remain instream (Vörösmarty et al., 2010). Indeed, the study area has a long history of drought, including record drought during the 1950s through which pelagic-spawning fishes persisted. However, following fragmentation and consequently dewatering, the effects of drought became increasingly effective at causing declines among pelagic-spawning fishes even in the largest of the remaining stream fragments, as illustrated here on at least three occasions. First, the drought cycle of 2001-2003 caused punctuated decline, but not extirpation, of plains minnow and peppered chub in the Arkansas River. Second, following the 2001-2003 drought cycle, occurrences of both species remained low until the next drought cycle of 2005-2007, during which plains minnow occurrence declined to zero. Third, during the drought cycle of 2010-2013, the probability of occurrence for peppered chub closely followed the pattern of plains minnow during the previous drought cycle, including declining to zero occurrence. It is interesting that only one other drought period (i.e. 1994) caused exceptionally low flows in both the Arkansas and Ninnescah rivers, and plains minnow and peppered chub both persisted, although we hypothesize that declines similar to 2001-2003 probably occurred during 1993-1995. Additional historical data are necessary to test this hypothesis; however, it could be that the exceptionally high flow years (1993 and 1995) that bound the low flow year of 1994 buffered populations against the effects of punctuated drought. Thus, antecedent flows combined with stochastic drought affecting broad spatial extents (i.e. the entire sub-basin) contributed to punctuated disappearance of pelagic-spawning fishes.

We hypothesize that loss of pelagic-spawning fishes from the Arkansas and Ninnescah rivers 
represents an ecological ratchet mechanism in motion. Ratcheting begins when the longitudinal connectivity of a stream is fragmented by barriers (Figure 6(A)). Communities within longitudinal zones of the river are effectively isolated and the effects of local community structuring become decoupled from regional immigration (Angermeier and Winston, 1998). Species that require habitat connectivity at broad spatial scales are lost from short stream fragments even in the absence of stochastic disturbance (Perkin and Gido, 2011; Wilde and Urbanczyk, 2013). Communities in upstream portions of riverscapes are most vulnerable to environmental variability (Schlosser, 1990) and the effects of ratcheting are first evident in these habitats at relatively minor disturbances (Figure 6(B)). During minor drought, pelagic-spawning fishes that depend on broad levels of riverscape connectivity or greater discharge magnitudes decline but are not lost from the riverscape (Wilde and Durham, 2008). At this stage, if the drought cycle subsides and flows return to normal, a ratchet cycle may be averted (i.e. a 'pseudo' ratchet cycle). The ratchet manifests itself when stochastic disturbances such as drought or anthropogenic dewatering induce stream contraction and drying (Figure 6(C)). Pelagic-spawning fishes that were extirpated from small fragments upstream of dams now decline and are eventually lost from large downstream fragments (Worthington et al., 2014). At this stage, availability and suitability of refuge habitats such as downstream impoundments select for persistence of species based on reproductive mechanisms, and non-pelagic-spawning fishes are at an advantage (Sedell et al., 1990; Dudley and Platania, 2007). Ratcheting inflicts legacy effects when portions of the riverscape are re-wetted and artefacts of the disturbance persist because species diversity is now lower (Figure 6(D)). Each turn of the ratchet represents the loss of a single species; thus, we hypothesize that the ratchet has made up to three turns in the study system: the first affecting Arkansas River shiner, the second plains minnow, and the third and most recent peppered chub. In this context, contemporary community composition reflects current levels of fragmentation together with legacies of historical disturbances, and these 'ghosts of riverscapes past' probably haunt other stream networks in the Great Plains (Kelsch, 1994; Perkin et al., 2013b).

\section{Evidence for ratchets}

Riverscapes throughout the Great Plains now resemble a mosaic of stream fragments isolated by agents of fragmentation such as road crossings, small dams, large impoundments, and desiccated stream segments (Matthews and Marsh-Matthews,

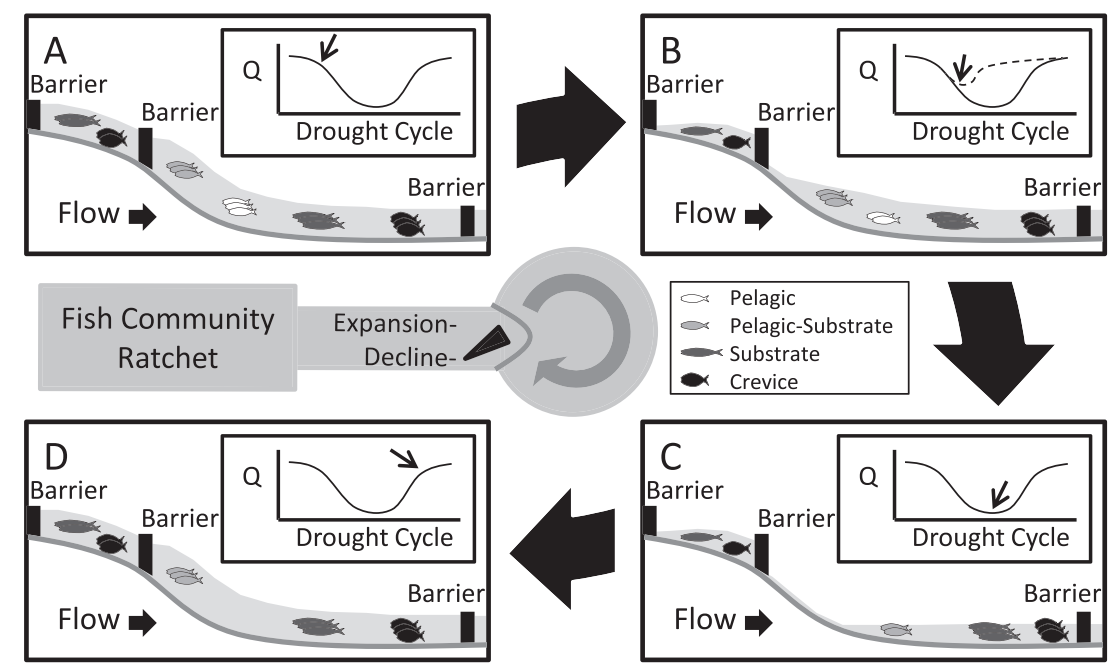

Figure 6. Conceptual diagram of the ecological ratchet mechanism caused by interactions between habitat fragmentation and drought. Ratchets can operate as mechanisms for population expansion or decline (shown here) and involve forward movement without reciprocated reverse movement through four stages in a fragmented riverscape: (A) before drought; (B) onset of drought; (C) height of drought; and (D) following drought. Fish abundance is equal to the number of symbols; if a drought subsides (dashed line of insert in B) then a 'pseudo ratchet cycle' ensues. 
2007; Perkin et al., 2014). Within the fragments of stream between these barriers, natural and human disturbances act upon smaller and isolated populations of stream organisms characterized by an impaired ability to resist and subsequently recover from stochastic disturbances (Sedell et al., 1990). This process is probably magnified by alteration of natural gradients along the river continuum (Ward and Stanford, 1983). In theory, stochastic and deterministic disturbances brought on by human activities involve water pollution, introduction of non-native species, regulated streamflow regimes, and artificial dewatering caused by water diversion and withdrawal (Hoagstrom et al., 2011). The unifying theme among these examples involves community change driven by disturbance and in the absence of colonization from outside sources. Legacies or historical contingencies arising from such disturbances leave lasting effects on the isolated fish communities within stream fragments and have undoubtedly contributed to the strong relationship between fragment length and the persistence of some fishes (Perkin and Gido, 2011; Wilde and Urbanczyk, 2013). Application of the ecological ratcheting framework to fragmented riverscapes constitutes the testing of general ecological and landscape theory with potential to enhance conservation of biodiversity in fragmented stream ecosystems on a global scale (Bain and Wine, 2010; Liermann et al., 2012).

\section{Implications for conservation}

Conservation actions can counter the effects of the described ecological ratchet involving fragmentation and desiccation in at least four ways to benefit fishes in fragmented rivers on a global scale (Liermann et al., 2012). First, longitudinal connectivity might be improved through documentation and prioritized removal of barriers (Fullerton et al., 2010; Januchowski-Hartley et al., 2013). This process has already helped to improve the distribution and abundance of pelagic-spawning cyprinids (Archdeacon and Remshardt, 2012) as well as other stream species (Catalano et al., 2007; Hitt et al., 2012). Second, flow regimes might be manipulated to enhance recruitment and persistence of a variety of stream organisms (Propst and Gido, 2004; Konrad et al., 2011; Kiernan et al., 2012). Third, in the absence of capacity to regulate streamflow, rescuing individuals from drying stream fragments and holding them in captivity until flows recover is one option recently used for pelagic-spawning fishes in the upper Brazos River of Texas (Kevin Mayes, Texas Parks and Wildlife Department, personal communication). However, such reactive approaches will not be effective in perpetuity and require significant resources first to rescue and then to hold species until drought conditions subside. Forth, for stream fragments in which species are now extirpated but environmental conditions have improved following disturbance, repatriation of fishes obtained from genetic reservoirs is an emerging technique that might allow for the re-establishment of self-sustaining populations (Osborne et al., 2013). However, the long-term outlook for re-establishing populations will depend entirely on slowing down ratcheting so that genetic reservoirs for declining species persist. As slowing ratcheting will become increasingly challenging under the expected warmer and drier climatic conditions of the future (Milly et al., 2005), implementing sustainable water management approaches aimed at conserving freshwater resources is crucial (Vörösmarty et al., 2010; Steward et al., 2013).

\section{ACKNOWLEDGEMENTS}

This work was funded by the Kansas Department of Wildlife, Parks and Tourism (KDWPT) and the Great Plains Landscape Conservation Cooperative. Fishes were collected with permission from the KDWPT (permits SC-051-2011 and SC-057-2012 issued to $\mathrm{KBG}$ ) as well as the Institutional Animal Care and Use Committee at Kansas State University (permit 2996). J. Edmonds, D. Shaw, and T. Starks provided extensive field assistance during long, hot summer days. We thank N. Cathcart, J. Fischer, S. Hedden, K. Kirkbride, E. Martin, B. Scharping, M. Troia, and J. Whitney for occasional sampling trips. Valuable logistical support was provided by A. Austin, J. Conley, A. Lollar, J. Luginbill, and R. Waters with the KDWPT. We are grateful to numerous private land owners as well as Wichita State University for granting access to the Ninnescah River. Data for the Arkansas River 
near the City of Wichita were graciously provided by V. Weaver. Finally, L. Fallis, M. Troia, D. Larson, and A. Veach provided helpful comments on earlier versions of the manuscript.

\section{REFERENCES}

Angermeier PL, Winston MR. 1998. Local vs. regional influences on local diversity in stream fish communities of Virginia. Ecology 79: 911-927.

Archdeacon TP, Remshardt WJ. 2012. Observations of hatchery-reared Rio Grande silvery minnow using a fishway. North American Journal of Fisheries Management 32: 648-655.

Bain MB, Wine LM. 2010. Testing predictions of stream landscape theory for fish assemblages in highly fragmented watersheds. Folia Zoology 59: 231-239.

Balon EK. 1975. Reproductive guilds of fishes: a proposal and definition. Journal of the Fisheries Research Board of Canada 32: $821-864$.

Birkeland C. 2004. Ratcheting down the coral reefs. BioScience 54: $1021-1027$.

Bray JR, Curtis JT. 1957. An ordination of the upland forest communities of southern Wisconsin. Ecological Monographs 27: 325-349.

Caddy JF, Gulland JA. 1983. Historical patterns of fish stocks. Marine Policy 7: 267-278.

Campbell Grant EH, Lowe WH, Fagan WF. 2007. Living in the branches: population dynamics and ecological processes in dendritic networks. Ecology Letters 10: 165-175.

Catalano MJ, Bozek MA, Pellett TD. 2007. Effects of dam removal on fish assemblage structure and spatial distributions in the Baraboo River, Wisconsin. North American Journal of Fisheries Management 27: 519-530.

Cooke SJ, Paukert C, Hogan Z. 2012. Endangered river fish: factors hindering conservation and restoration. Endangered Species Research 17: 179-191.

Costigan KH, Daniels MD. 2012. Damming the prairie: human alteration of Great Plains river regimes. Journal of Hydrology 444: 90-99.

Costigan KH, Daniels MD, Perkin JS, Gido KB. 2014. Longitudinal variability in hydraulic geometry and substrate characteristics of a Great Plains sand-bed river. Geomorphology 210: 48-58.

Cote D, Kehler DG, Bourne C, Wiersma WF. 2009. A new measure of longitudinal connectivity for stream networks. Landscape Ecology 24: 101-113.

Cross FB. 1967. Handbook of Fishes of Kansas. University of Kansas Press: Lawrence, KS.

Cross FB, Collins JT. 1995. Fishes in Kansas, 2nd edn. University of Kansas Press: Lawrence, KS.

Cross FB, Moss RE, Collins JT. 1985. Assessment of dewatering impacts on stream fisheries in the Arkansas and Cimarron rivers. The University of Kansas Museum of Natural History, Lawrence, Kansas.

Dodds WK, Gido KB, Whiles MR, Fritz KM, Matthews WJ. 2004. Life on the edge: ecology of Great Plains prairie streams. BioScience 54: 205-216.

Dudgeon D, Arthington AH, Gessner MO, Kawabata ZI, Knowler DJ, Lévêque C, Naiman RJ, Prieur-Richard AH,
Soto D, Stiassny MLJ, Sullivan CA. 2006. Freshwater biodiversity: importance, threats, status and conservation challenges. Biological Reviews 81: 163-182.

Dudley RK, Platania SP. 2007. Flow regulation and fragmentation imperil pelagic-spawning riverine fishes. Ecological Applications 17: 2074-2086.

Dunham JB, Young MK, Gresswell RE, Rieman BE. 2004. Effects of fire on fish populations: landscape perspectives on persistence of native fishes and nonnative fish invasions. Forest Ecology and Management 178: 183-196.

Durham BW, Wilde GR. 2009. Effects of streamflow and intermittency on the reproductive success of two broadcast-spawning cyprinid fishes. Copeia 2009: 21-28.

Falke JA, Fausch KD, Magelky R, Aldred A, Durnford DS, Riley LK, Oad R. 2011. The role of groundwater pumping and drought in shaping ecological futures for stream fishes in a dryland river basin of the western Great Plains, USA. Ecohydrology 4: 982-697.

Fausch KD, Torgersen CE, Baxter CV, Li HW. 2002. Landscapes to riverscapes: bridging the gap between research and conservation of stream fishes. BioScience 52: 483-498.

Fullerton AH, Burnett KM, Steel EA, Flitcroft RL, Pess GR, Feist BE, Torgersen CE, Miller DJ, Sanderson BL. 2010. Hydrological connectivity for riverine fish: measurement challenges and research opportunities. Freshwater Biology 55: $2215-2237$.

Gido KB, Guy CS, Strakosh TR, Bernot RJ, Hase KJ, Shaw MA. 2002. Long-term changes in the fish assemblages of the Big Blue River basin 40 years after the construction of Tuttle Creek Reservoir. Transactions of the Kansas Academy of Science 105: 193-208.

Gido KB, Dodds WK, Eberle ME. 2010. Retrospective analysis of fish community change during a half-century of landuse and streamflow changes. Journal of the North American Benthological Society 29: 970-987.

Halekoh U, Hojsgaard S, Yan J. 2006. The R package geepack for generalized estimating equations. Journal of Statistical Software 15: 1-11.

Hitt NP, Eyler S, Wofford JE. 2012. Dam removal increases American eel abundance in distant headwater streams. Transactions of the American Fisheries Society 141: 1171-1179.

Hoagstrom CW, Turner TF. 2013. Recruitment ecology of pelagic-broadcast spawning minnows: paradigms from the ocean advance science and conservation of an imperiled freshwater fauna. Fish and Fisheries DOI: 10.1111/faf.12054.

Hoagstrom CW, Brooks JE, Davenport SR. 2011. A large-scale conservation perspective considering endemic fishes of the North American plains. Biological Conservation 144: 21-34.

Jackson ST, Betancourt JL, Booth RK, Gray ST. 2009. Ecology and the ratchet of events: climate variability, niche dimensions, and species distributions. Proceedings of the National Academy of Sciences 106: 19685-19692.

Januchowski-Hartley SR, McIntyre PB, Diebel M, Doran PJ, Infante DM, Joseph C, Allan JD. 2013. Restoring aquatic ecosystem connectivity requires expanding inventories of both dams and road crossings. Frontiers in Ecology and the Environment 11: 211-217.

Jelks HL, Walsh SJ, Burkhead NM, Contreras-Balderas S, Diaz-Pardo D, Hendrickson DA, Lyons J, Mandrak NE, McCormick F, Nelson JS, et al. 2008. Conservation status of imperiled North American freshwater and diadromous fishes. Fisheries 33: 372-407. 
Junge J, Museth J, Hindar K, Kraabol M, Vollestad LA. 2014. Assessing the consequences of habitat fragmentation for two migratory salmonid fishes. Aquatic Conservation: Marine and Freshwater Ecosystems 24: 297-311.

Kelsch SW. 1994. Lotic fish-community structure following transition from severe drought to high discharge. Journal of Freshwater Ecology 9: 331-341.

KFGC (Kansas Fish and Game Commission). 1978. Lower Arkansas River basin Kansas stream Survey. Kansas Fish and Game Commission, Pratt, KS.

Kiernan JD, Moyle PB, Crain PK. 2012. Restoring native fish assemblages to a regulated California stream using the natural flow regime concept. Ecological Applications 22: $1472-1482$.

Konrad CP, Olden JD, Lytle DA, Melis TS, Schmidt JC, Bray EN, Freeman MC, Gido KB, Hemphill NP, Kennard MJ, et al. 2011. Large-scale flow experiments for managing river systems. BioScience 61: 948-959.

Lehner B, Liermann CR, Revenga C, Vörösmarty C, Fekete B, Crouzet P, Döll P, Endejan M, Frenken K, Magome J, et al. 2011. High-resolution mapping of the world's reservoirs and dams for sustainable river-flow management. Frontiers in Ecology and the Environment 9: 494-502.

Liermann CR, Nilsson C, Robertson J, Ng RY. 2012. Implications of dam obstruction for global freshwater fish diversity. BioScience 62: 539-548.

Ludwig D, Hilbom R, Waiters C. 1993. Uncertainty, resource exploitation, and conservation: lessons from history. Science 260: $17-18$.

Luttrell GR, Echelle AA, Fisher WL, Eisenhour DJ. 1999. Declining status of two species of the Macrhybopsis aestivalis complex (Teleostei: Cyprinidae) in the Arkansas River Basin and related effects of reservoirs as barriers to dispersal. Copeia 1999: 981-989.

Matthews WJ, Marsh-Matthews E. 2003. Effects of drought on fish across axes of space, time and ecological complexity. Freshwater Biology 48: 1232-1253.

Matthews WJ, Marsh-Matthews E. 2007. Extirpation of red shiner in direct tributaries of Lake Texoma (Oklahoma-Texas): a cautionary case history from a fragmented river-reservoir system. Transactions of the American Fisheries Society 136: 1041-1062.

Milly PC, Dunne KA, Vecchia AC. 2005. Global pattern of trends in streamflow and water availability in a changing climate. Nature 438: 347-350.

Oksanen J, Kindt R, Legendre P, O’Hara B, Simpson GL, Solymos P, Stevens MHH, Wagner H. 2007. Vegan: community ecology package. $<$ http://cran.r-project.org/>.

Osborne MJ, Diver TA, Turner TF. 2013. Introduced populations as genetic reservoirs for imperiled species: a case study of the Arkansas River Shiner (Notropis girardi). Conservation Genetics 14: 637-647.

Pardini R, de Arruda Bueno A, Gardner TA, Prado PI, Metzger JP. 2010. Beyond the fragmentation threshold hypothesis: regime shifts in biodiversity across fragmented landscapes. Plos One 5: e13666.

Patton TM, Rahel FJ, Hubert WA. 1998. Using historical data to assess changes in Wyoming's fish fauna. Conservation Biology 12: 1120-1128.

Perkin JS, Gido KB. 2011. Stream fragmentation thresholds for a reproductive guild of Great Plains fishes. Fisheries 36: $371-383$.
Perkin JS, Gido KB. 2012. Fragmentation alters stream fish community structure in dendritic ecological networks. Ecological Applications 22: 2176-2187.

Perkin JS, Gido KB, Al-Ta'ani O, Scoglio C. 2013a. Simulating fish dispersal in stream networks fragmented by multiple road crossings. Ecological Modelling 257: 44-56.

Perkin JS, Shattuck ZR, Gerken JE, Bonner TH. 2013b Fragmentation and drought legacy correlate with distribution of burrhead chub in subtropical streams of North America. Transactions of the American Fisheries Society 142: 1287-1298.

Perkin JS, Gido KB, Cooper AR, Turner TF, Osborne MJ, Johnson ER, Mayes KB. 2014. Fragmentation and dewatering transform Great Plains stream fish communities. Ecological Monographs online preprint doi:10.1890/14-0121.1.

Poff NL, Ward JV. 1989. Implications of streamflow variability and predictability for lotic community structure: a regional analysis of streamflow patterns. Canadian Journal of Fisheries and Aquatic Sciences 46: 1805-1818.

Pringle C. 2003. The need for a more predictive understanding of hydrologic connectivity. Aquatic Conservation: Marine and Freshwater Ecosystems 13: 467-471.

Propst DL, Gido KB. 2004. Responses of native and nonnative fishes to natural flow regime mimicry in the San Juan River. Transactions of the American Fisheries Society 133: 922-931.

Richter BD, Baumgartner JV, Powell J, Braun DP. 1996. A method for assessing hydrologic alteration within ecosystems. Conservation Biology 10: 1163-1174.

Roberts JJ, Fausch KD, Peterson DP, Hooten MB. 2013. Fragmentation and thermal risks from climate change interact to affect persistence of native trout in the Colorado River basin. Global Change Biology 19: 1383-1398.

Rolls RJ, Ellison T, Faggotter S, Roberts DT. 2013. Consequences of connectivity alteration on riverine fish assemblages: potential opportunities to overcome constraints in applying conventional monitoring designs. Aquatic Conservation: Marine and Freshwater Ecosystems 23: 624-640.

Roques L, Stoica RS. 2007. Species persistence decreases with habitat fragmentation: an analysis in periodic stochastic environments. Journal of Mathematical Biology 55: 189-205.

Schlosser IJ. 1990. Environmental variation, life history attributes, and community structure in stream fishes: implications for environmental management and assessment. Environmental Management 14: 621-628.

Sedell JR, Reeves GH, Hauer FR, Stanford JA, Hawkins CP. 1990. Role of refugia in recovery from disturbances: modern fragmented and disconnected river systems. Environmental Management 14: 711-724.

Simon TP. 1999. Assessment of Balon's reproductive guilds with application to Midwestern North American freshwater fishes. In Assessing the Sustainability and Biological Integrity of Water Resources Using Fish Communities, Simon TP (ed). CRC Press: New York; 97-121.

Steward DR, Bruss PJ, Yang X, Staggenborg SA, Welch SM, Apley MD. 2013. Tapping unsustainable groundwater stores for agricultural production in the High Plains Aquifer of Kansas, projections to 2110. Proceedings of the National Academy of Sciences 110: E3477-E3486.

Thrush SF, Dayton PK. 2010. What can ecology contribute to ecosystem-based management? Annual Review of Marine Science 2: 419-441.

Vörösmarty CJ, McIntyre PB, Gessner MO, Dudgeon D, Prusevich A, Green P, Glidden S, Bunn SE, Sullivan CA, 
Liermann CR, Davies PM. 2010. Global threats to human water security and river biodiversity. Nature 467: 555-561.

Ward JV, Stanford JA. 1983. The serial discontinuity concept of lotic ecosystems. In Dynamics of Lotic Ecosystems, Fontaine TD III, Bartell SM (eds). Ann Arbor Science: Ann Arbor, MI; 29-42.

Wilde GR. 2002. Threatened fishes of the world: Notropis girardi Hubbs \& Ortenburger 1929 (Cyprinidae). Environmental Biology of Fishes 65: 98-98.

Wilde GR, Durham BW. 2008. A life history model for peppered chub, a broadcast-spawning cyprinid. Transactions of the American Fisheries Society 137: 1657-1666.

Wilde GR, Urbanczyk AC. 2013. Relationship between river fragment length and persistence of two imperiled Great Plains cyprinids. Journal of Freshwater Ecology 28: 445-451.

Winston MR, Taylor CM, Pigg J. 1991. Upstream extirpation of four minnow species due to damming of a prairie stream. Transactions of the American Fisheries Society 120: 98-105.

Worthington TA, Brewer SK, Grabowski TB, Mueller J. 2014. Backcasting the decline of a vulnerable Great Plains reproductive ecotype: identifying threats and conservation priorities. Global Change Biology 20: 89-102.

Zuur AE, Ieno N, Walker NJ, Saveliev AA, Smith GM. 2009. Mixed Effects Models and Extensions in Ecology with $R$. Springer: New York.

\section{SUPPORTING INFORMATION}

Additional supporting information may be found in the online version of this article at the publisher's web site. 